\title{
NILAI-NILAI DAKWAH DALAM LONTARA TARO ADA TARO GAU (STUDI KEPEMIMPINAN RUMAH TANGGA DI KABUPATEN BONE)
}

\author{
SYAFRIANA \\ Pascasarjana UIN Alauddin Makassar \\ Email: Syafriana.riana7@gmail.com
}

\begin{abstract}
:
Basically, Islam is very dominant in shaping the behaviour of the Bugis in communication, because after all the valuaes of the Bugis culture has undergone a process of islamization, namely when the entry of elements sara' coloring and becoming a spirit of other elements in pangadereng, so that the joints are no longer in conflict with religion Islam. If a leader has the desire and determination to implement communication behavior taro ada taro gau, then realize in the leadership of the household, then it is a very good effort in maintaining the integrity of the house. Bugis people usually do family outreach about advice like this. Later it will grow from individuals to families to become community units that implement behaviour taro ada taro gau. There are four main values in lontara taro ada taro gau, that is macca or to acca (smart), malempu (honest), magetteng na warani (strong and brave) dan Manini (through).
\end{abstract}

Keywords : Taro ada taro gau, pangadereng, lontara, household leadership.

\section{PENDAHULUAN}

Hakikat perkawinan merupakan penyatuan dua lawan jenis anak adam laki-laki dan perempuan dalam sebuah ikatan ritual agama yang menghalalkan hubungan biologis diantara keduanya serta menyatukan antara kedua keluarga suku dan negara. Atas dasar komitmen antara laki-laki dan perempuan yang bersumber dari cinta Ilahi. Oleh karena itu dapat dikatakan bahwa hukum asal dari perkawinan itu adalah boleh atau mubah. Dengan demikian, dapat dikatakan bahwa dengan adanya akad perkawinan pergaulan antara laki-laki dengan perempuan menjadi mubah. ${ }^{1}$ Di antara firmanNya dalam QS surat An-Nuur /24:32:

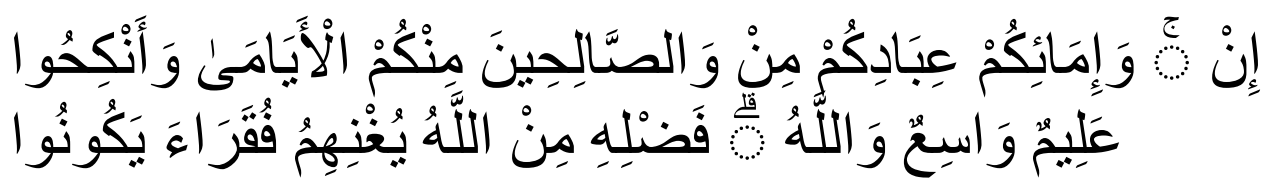

Terjemahnya: Dan kawinkanlah orang-orang yang sedirian diantara kamu, dan orang-orang yang layak (berkawin) dari hamba-hamba sahayamu yang lelaki dan hamba-hamba sahayamu yang perempuan. jika

\footnotetext{
${ }^{1}$ Amir Syarifuddin, Hukum Perkawinan Islam di Indonesia, Kencana, Jakarta, 2006, h.
} 43. 
mereka miskin Allah akan memampukan mereka dengan kurniaNya. dan Allah Maha Luas (pemberian-Nya) lagi Maha mengetahui. $^{2}$

Maksudnya: hendaklah laki-laki yang belum kawin atau wanita- wanita yang tidak bersuami, dibantu agar mereka dapat kawin.

Pernikahan merupakan suatu ikrar janji kesetiaan dan terciptanya pola hubungan yang harmonis saling jujur, percaya dan pengertian antara suami dan istri dengan tujuan pencapaian ridha Allah Swt. Ikatan suatu pernikahan yang diniatkan mencari ridha Allah jauh lebih mulia ketimbang diniatkan yang lain. Sebab dalam pernikahan tersebut akan mendapatkan keberkahan dan usia pernikahan akan langgeng serta terus berkesinambungan. Tentunya suami dan istri akan mendapatkan pola hubungan yang bahagia bukan hanya sesaat melainkan dunia akhirat kelak. ${ }^{3}$ Tanpa pernikahan tidak mungkin seorang laki-laki dan perempuan dapat membentuk dan mengatur tatanan kehidupan keluarga yang dalam bahasa keseharian :" sakinah mawaddah warahmah". Aman, tentram saling mencintai dan saling mengasihi, serta saling menyayangi. ${ }^{4}$

Tujuan perkawinan dalam Islam adalah untuk memenuhi tuntutan naluri hidup manusia, berhubungan dengan laki-laki dan perempuan, dalam rangka mewujudkan kebahagiaan keluarga sesuai ajaran Allah dan Rasul-Nya. Dengan pernikahan maka dapat mewujudkan kehidupan rumah tangga yang sakinah, mawaddah, dan rahmah (keluarga yang tentram penuh kasih sayang).

Harapan utama sebuah pernikahan adalah meraih kebahagiaan. Dengan perasaan kasih sayang yang dimiliki oleh masing-masing pasangan akan membuat sebuah hubungan harmonis yang nantinya akan berakhir dengan sebuah kebahagiaan. Selain harapan akan kebahagiaan, dalam pernikahan juga terdapat berbagai harapan lain seperti; meneruskan keturunan, membentuk keluarga harmonis, menjadikan pribadi yang lebih baik. Tujuan dari perkawinan adalah untuk memperoleh ketentraman, kecintaan dan kasih sayang, sehingga dapat tercipta keluarga yang bahagia dan kekal berdasarkan Ketuhanan Yang Maha Esa. $^{5}$

Ketika sebuah pernikahan telah berhasil dibina oleh pasangan suami istri, keduanya tentu mengharap adanya keturunan. Hadirnya seorang anak dalam

\footnotetext{
${ }^{2}$ Kementrian Agama RI. Al-Qur'an dan Terjemahannya, (Jakarta, Direktorat Jendral Bimbingan Masyarakat Islam dan Urusan Agama Islam dan Bimbingan Syariah, 2012), h. 354.

${ }^{3}$ https://www.scribd.com/doc/315538155/Hakikat-Dan-Tujuan-Pernikahan-dalam-Islam. Diakses pada 16 Juli 2019.

${ }^{4}$ Zakiah Darajat, Dkk. Dasar-Dasar Agama Islam.(Jakarta: Bulan Bintang 1984). h. 34.

${ }^{5}$ Undang-Undang No.1 Tahun 1974 Tentang Perkawinan, Arkola, Surabaya, h. 5.
} 
sebuah pernikahan bukanlah menjadi alasan bagi pasangan suami istri menghilangkan rasa sayang keduanya untuk digantikan kepada buah hatinya. Tujuan hidup seorang laki-laki dan perempuan yang telah melaksanakan pernikahan adalah membina bahtera rumah tangga di dalam sebuah keluarga yang bahagia dan sejahtera. Usaha dalam mengatasi problematika rumah tangga dan menjaga hubungan baik antara satu dengan yang lain hanyalah karena Allah yaitu mencapai keluarga sakinah, mawaddah, warahmah.

\section{TINJAUAN TEORITIS}

\section{Tinjauan Teoritis Tentang Dakwah dan Kearifan Lokal}

Untuk memahami dakwah secara tepat, maka perlu dikemukakan berbagai pengertian dakwah, baik secara etimologis maupun termologinya, sehingga akan di temukan makna dakwah dalam pengertian bahasa maupun istilahnya.Secara etimologis, kata "dakwah" adalah bentuk masdardari kata ( $f$ ' $i l$ madzhi) dan ( $f$ ' $i l$ mudhori) yang berarti memanggil, mengundang, mengajak, menyeru, mendorong dan memohon. ${ }^{6}$ Sedangkan menurut Muhammad Husain Fadhlullah Al-Hasani secara bahasa kata dakwah cukup aktifitas amar ma'ruf nahi mungkar.

Pemaknaan yang demikian berdasarkan pada kenytaan, bahwa amar ma'ruf nahi mungkar merupakan praktik dakwah untuk mengajar orang dan mengikuti kebaikan, sedangkan kegiatan nahi mungkar merupakan eplaksanaan dakwah untuk mengajak orang untuk menjauhi dan meninggalkan segala perbuatan mungkar dan jelek. Oleh karena itu, kedua kegiatan tersebut memiliki makna dakwah dan ajakan dakwah untuk berbuat keshalihan, baik melakukan perbuatan yang baik maupun tidak melakukan segala yang jelek dan mungkar. ${ }^{7}$

Secara istilah (terminologi) dakwah dapat diartikan sebagaisisi positif dari ajakan untuk menuju keselamatan dunia dan akhirat. Para pakar sendiri memberikan definisi berbeda-beda mengenai dakwah diantaranya:

Menurut Arifin definisi dakwah adalah suatu ajakan baik berbentuk lisan, tulisan, tingkah laku dan sebagainya, yang dilakukan secara sadar dan berencana dalam usaha mempengaruhi orang lain secara individu maupun kelompok agar timbul dalam dirinya satu pengertian, kesadaran sikap penghayatan serta pengalaman terhadap pengajaran agama sebagai message yang disampaikan kepadanya tanpa adanya unsur paksaan. ${ }^{8}$

Dakwah adalah upaya konstuktif seseorang untuk melakukan perubahan

1.

${ }^{6}$ Siti Muriah,. Metodologi Dakwah Kontenporer. (Yogyakarta: Mitra Pustaka. 2000), h.

10.

${ }^{7}$ M. Husain Fadlullah, Metodologi Dakwah Dalam Al-Qur'an. Jakarta: Lentera. 1997,h.

${ }^{8}$ M Arifin, Psikologi Dakwah suatu Pengantar. Jakarta. Bumi aksara. 1997, h. 6. 
suatu situasi yang negatif menjadi situasi positif dari beberapa pengertian di atas dapat disimpulkan bahwa dakwah merupakan suatu kegiatan untuk mengajak manusia dengan cara bijak sana baik dalam bentuk lisan, tulisan maupun tingkah laku yang mengarah kepada kebaikan atau kemaslahatan kepada orang lain baik individu maupun kelompok, orang tersebut melakukan kebaikan dan meninggalkan kemungkaran sesuai ajaran islam untuk mendapatkan kebahagiaan dunia dan akhirat, tanpa adanya unsur paksaan.

Kearifan lokal dalam kamus inggris indonesia, terdiri dari dua kata yaitu kearifan (wisdom) dan lokal (local). Lokal berarti setempat dan wisdom sama dengan kebijaksanaan. ${ }^{9}$ Maka lokal wisdom dapat dipahami sebagai gagasangagasan, nilai-nilai, pandangan-pandangan setempat (lokal) yang bersifat bijaksana, penuh kearifan, bernilai baik, yang tertanam dan diikuti oleh anggota masyarakatnya. Kearifan lokal disamakan dengan budaya lokal, yakni adat dan tradisi masyarakat setempat secara lokal berdasarkan peta dan batas wilayah tertentu. Kearifan lokal (lokal genius) adalah kebenaran yang telah mentradisi dalam suatu daerah yang merupakan perpaduan antara nilai-nilai suci firman Tuhan dalam berbagai nilai yang ada, dan terbentuk sebagai keunggulan budaya masyarakat setempat maupun kondisi geografis dalam arti luas yang merupakan produk budaya masa lalu yang patut secara terus menerus dijadikan pegangan hidup. Meskipun bernilai lokal tetapi nilai yang terkandung didalamnya dianggap sangat universal. ${ }^{10}$

Unsur-unsur kearifan lokal bersumber dari budaya setempat yang dihasilkan pikiran dan akal budi berdasarkan pengalaman yang berbentuk adat istiadat kemudian melahirkan kebudayaan yakni, suatu keseluruhan yang kompleks terjadi dari unsur-unsur berbeda seperti pengetahuan, kepercayaan, seni dan budaya pada masyarakat setempat. Jadi masyarakat yang dimaksud adalah masyarakat Bugis Bone yang akan menjadi objek penelitian mengenai filsafat Bugis taro ada taro gau dalam penerapan kepemimpinan rumah tangga.

Masyarakat Bugis merupakan salah satu suku bangsa yang kuat berpegang pada adat (ade'). Menurut pemahaman masyarakat Bugis bahwa ade' sebagai esensi manusia, ade' itulah yang menyebabkan seseorang disebut manusia. Seorang yang tidak mengetahui, tidak menghayati, dan tidak memerankan diri dengan ade' maka tidak dapat disebut manusia. Dari ade' itulah manusia berpangkal. Tanpa ade' yang menjadi pangkal kemanusiaan, maka apa yang disebut lempu'(kejujuran), takwa kepada Allah dan mempertinggi siri' sebagai

9 M.John Echols dan Hassan Sadly, an Englis-Indonesia Dictionary: Kamus Inggris Indonesia (Cet XXXIII: Jakarta: Gramedia Pustaka, 2006), h. 649.

${ }^{10}$ Ayatrohaedi, kepribadian Budaya Bugis: Lokal Genius (jakarta: Pustaka Jaya, 2006), h. 18-19. 
nilai dan martabat kemanusiaan, tidak mungkin terwujud.Ade' (adat) bagi orang Bugis itu adalah nilai dan harga dirinya. Aturan-aturan itu disebut pangngaderreng. Di dalamnya terdapat aturan-aturan yang menata kehidupan manusia. Nilai-nilai yang terdapat dalam kebudayaan orang Bugis itu perlu diungkapkan dalam setiap gerak kehidupan orang bugis dalam menghadapi setiap dinamika kehidupan yang penuh tantangan. Nilai-nilai itu diciptakan karena dimuliakan oleh para leluhur mereka sebagai peletak dasar masyarakat dan kebudayaan bugis. Selanjutnya, dialihkan dari suatu generasi ke generasi berikutnya. Dalam upaya mewariskannya, ia menyampaikan dalam bentuk nasihat atau pesan. Nasihat dan petaruh itu terdapat dalam lontara'-lontara'yang disebut pappanngaja dan paseng. Masyarakat dan kebudayaan bugis dapat ditelusuri dalam beberapa sumber dan literatur, misalnya dalam "Nilai-Nilai Utama Kebudayaan Bugis". Kebudayaan orang Bugis mempunyai nilai-nilai utama berupa kejujuran, kecendikiaan, kepatutan, keteguhan, usaha atau kerja keras.

Setelah Islam dianut oleh masyarakat Bone, maka pangngadereng mengalami pengembangan yaitu sara' (syariat Islam) ditetapkan menjadi salah satu unsur pangngadereng. "Kendatipun sara' menjadi unsur terakhir, tidak berarti ditempatkan pada posisi yang berbeda dengan unsur lainnya, melainkan mempunyai posisi yang sama. Hal ini dapat dilihat dalam ungkapan lontara", yang dituturkan kembali oleh Andi Muhammad Ali Petta Nompo mengenai hubungan antara ade' dan sara', sebagai berikut:

Mappakarajai sara'e ri ade'e, mappakalebbi'I ade'e ri sara'e, temmakkullei ade'e narusa' taro bicaranna sara'e, temmakkullei toi sara'e narusa' tarobicaranna ade'e, pusai ade'e ritarobicaranna massappai ritarobicaranna sara'e, pusai sara'e ritarobicaranna massappai ade'e, temmakkullei sipusang-pusang iya duwa, temmakkulleitoe sirusa' iya duwa. Terjemahnya :

Syari'at menghormati adat, adat menghormati syari'at, pantang adat membatalkan keputusan syari'at dan pantang juga syari'at membatalkan keputusan adat, jika sesuatu hal tidak ditemukan dalam aturan adat, akan dicari dalam aturan syari'at, jika sesuatu tidak ditemukan dalam aturan syari'at akan dicari dalam aturan adat, tidak mungkin keduanya saling mengaburkan, tidak mungkin keduanya saling merusak/ bertentangan.

Pernyataan tersebut menunjukkan bahwa antara pangngadereng dan syari'at mempunyai hubungan yang saling melengkapi. Bahkan setelah masuknya agama Islam di kerajaan Bone, nilai-nilai pangngadereng yang empat menerima 
sara' sebagai salah satu unsur pangngadereng. ${ }^{11}$

\section{PEMBAHASAN}

\section{Nilai Kepemimpinan Taro Ada Taro Gau dalam Islam}

Menjadi seorang pemimpin bukanlah perkara yang mudah bagi setiap orang. Seorang pemimpin harus memiliki kemampuan untuk bisa mengayomi setiap lapisan masyarakat atau keluarga yang dipimpinnya. Kemampuan untuk bersikap adil juga sangat menentukan kemajuan yang dipimpinnya.

Perkawinan bagi seorang muslim adalah merupakan bagian dari ajaran agama dimana melaksanakannya merupakan ibadah. Oleh karena menikah adalah ibadah, wajarlah jika memiliki tujuan-tujuan yang mulia dan hikmah yang besar pula. Tujuan perkawinan dalam ajaran agama Islam ialah pertama, adalah membentuk keluarga yang sakinah mawaddah dan warahmah. Sebagaimana firman Allah dalam Qs Ar-Ruum/30:21:

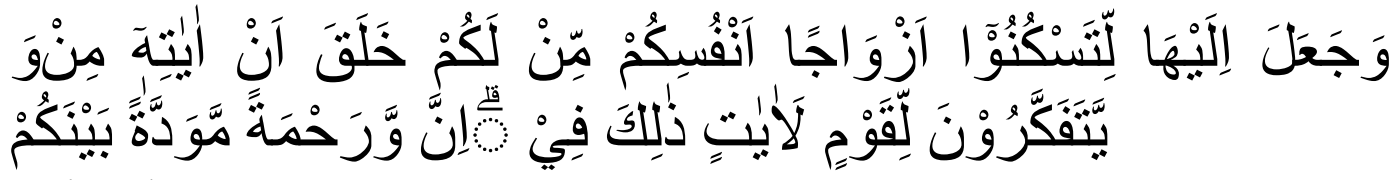

Terjemahnya:

Dan di antara tanda-tanda kekuasaan-Nya ialah dia menciptakan untukmu isteri-isteri dari jenismu sendiri, supaya kamu cenderung dan merasa tentram kepadanya, dan dijadikan-Nya diantara mu rasa kasih sayang. Sesungguhnya pada yang demikian itu benar-benar terdapat tanda-tanda bagi kaum yang berfikir. ${ }^{12}$

Kedua, untuk memelihara pandangan dan mata dari maksiat dan menjaga kehormatan diri sebagaimana sabda Rasulullah Saw, yang artinya: Dari Abdullah bin Mas'ud ia berkata telah bersabda kepada kami Rasulullah Saw, “ Wahai para pemuda, barang siapa diantara kalian memiliki kemampuan untuk kawin maka hendaklah ia kawin karena sesungguhnya kawin itu menghalangi pandangan (terhadap apa yang dilarang oleh agama) dan memelihara kemaluan. Dan barang siapa yang belum sanggup hendaklah ia berpuasa karena puasa itu adalah perias baginya." (H.R Bukhari dan Muslim).

Ketiga, perkawinan dalam islam bertujuan untuk mendapatkan keturunan

\footnotetext{
${ }^{11}$ Rahmatunniar, "Kontekstualisasi Pangngadereng dalam Penegakan Syariat Islam pada Masyarakat Bugis Bone” (Al-Qalam 17, no. 1, 2011), h. 98-99. Diakses 14 September 2019

${ }^{12}$ Kementrian Agama RI. Al-Qur'an dan Terjemahannya, h. 406.
} 
yang sah serta sehat jasmani, rohani dan sosial. Keempat, mempererat dan memperluas hubungan kekeluargaan serta membangun hari deoan individu, keluarga, dan masyarakat yang lebih baik. ${ }^{13}$

Perkawinan merupakan suatu hal yang sangat penting dalam kehidupan manusia, karena dengan jalan perkawinan yang sah pergaulan antar laki-laki dan perempuan menjadi terhormat, sesuai dengan kedudukan manusia sebagai makhluk yang mulia.

Islam mensyariatkan adanya pernikahan yang dimaksudkan untuk mengatur perjodohan di antara manusia yang merupakan naluri biologis kemanusiaan, untuk meneruskan keturunan, memperoleh ketenangan hidup, menumbuhkan dan memupuk rasa kasih sayang antar suami istri serta mengandung nilan-nilai religiusitas.

Kepemimpinan dalam keluarga masih menjadi kajian menarik bagi masyarakat Indonesia, khususnya bagi gerakan feminisme. Banyaknya kajian ini didorong oleh keprihatinan terhadap kenyataan yang ada di masyarakat yang beranggapan bahwa laki-laki lebih unggul daripada perempuan dalam segala hal.

Al-Qur' an sendiri, sebagai pedoman hidup umat Islam, tidak membedakan manusia. Tingkat iman dan takwa yang membedakan mereka di hadapan Tuhan. Akan tetapi, ada beberapa ayat yang dijadikan sebagai legitimasi pembedaan itu. Misalnya, masalah penciptaan perempuan, konsep kesaksian dan kewarisan perempuan, termasuk juga kepemimpinan dalam keluarga. Ayat-ayat tersebut sering sekali oleh mufasir hanya ditafsirkan secara tekstual sehingga memposisikan perempuan pada posisi kedua setelah laki-laki.

Interpretasi Al-Qur'an bagi umat Islam merupakan tugas yang tidak boleh berhenti, sebagai bentuk upaya memahami pesan Ilahi. Hal ini karena sebagai kitab suci dan petunjuk umat Islam, Al-Qur'an memiliki berbagai dimensi untuk dapat dijadikan sebagai pegangan hidup dan penuntun arah gerak setiap Muslim dalam menjalani kehidupannya. Kehidupan ini penuh dengan keanekaragaman sehingga manusia mempunyai tugas untuk berpikir (tafakkur) logis dan selalu mengingat (tazakkur) akan kebesaran Allah Swt. ${ }^{14}$

Allah memberikan kepemimpinan kepada laki-laki (suami), karena mereka mengemban kewajiban yang lebih banyak dibanding wanita (istri), yakni memberikan nafkah, mahar, dan memberikan perlindungan. Oleh karena itu, istri harus melaksanakan perintah suaminya. Namun, dalam kepatuhan itu terkandung azas kebenaran. Sehingga seorang perempuan harus menerima kepemimpinan suami atas dirinya, manakala suami berada di jalan yang benar.

${ }^{13}$ Abd Rauf. Buku Saku Pengantin.(Majene.2011), h. 6-12.

14 Yusuf Qardhawi, Al-Qur'an Berbica tentang Akal dan ilmu Pengetahuan. (Jakarta: Gema Insani Press, 1998), h. 2. 
Oleh karena itu, laki laki diharapkan dapat menjalankan kewajibannya sebagai pemimpin yang bijaksana, yaitu tidak mengedepankan emosinya, yang dapat menimbulkan dampak negatif bagi keluarganya. Sedangkan kekuatan fisik terkait dengan kesempurnaan struktur tubuh yang lebih tangguh daripada perempuan, serta kesanggupan melakukan pekerjaan yang berat dengan tabah. Kondisi fisik yang kuat, menjadikan laki laki lebih kuat bekerja, sehingga mereka dapat memberi nafkah, melindungi, dan memimpin keluarganya.

Perilaku komunikasi orang bugis diwarnai oleh dua nilai yang tidak dapat dipisahkan (dua temmasserang) yakni nilai budaya dan ajaran agama Islam. dari kedua nilai tersebut saling mengisi dan melengkapi, masing-masing memiliki kesamaan yang menuntut adanya kejujuran dan perkataan benar dalam berkomunikasi dengan sesama makhluk. Kedua sistem nilai ini juga menuntut orang bugis untuk berprilaku yang relevan antara perbuatan dengan perkataannya atau dengan kata lain satunya kata dan perbuatan.

Pada dasarnya Islam sangat dominan membentuk prilaku orang Bugis dalam berkomunikasi, karena bagaimanapun nilai budaya Bugis telah mengalami proses islamisasi, yakni ketika masuknya unsur sara' mewarnai dan menjadi spirit unsur-unsur lainya dalam pangadereng, sehingga sendinya sudah tidak berbentangan lagi dengan ajaran agama Islam. secara ekstrim orang menganggap Bugis identik dengan Islam. hal ini pula menyebabkan, orang Bugis senantiasa menjadikan kata Assalamu 'alaikum sebagai ucapan awal ketika bertamu atau bertemu dengan orang lain.

Di tengah konteks kemajuan dalam masyarakat, prilaku taro ada taro gau makin langka, karena itu perlu dikembalikan dan diwariskan kepada anak-anak sebagai generasi penerus. Dengan demikian hidup rukun dan harmonis akan terealisasi dengan baik.

Jika seorang pemimpin memiliki keinginan dan tekad untuk menerapkan prilaku komunikasi taro ada taro gau, kemudian merealisasikan dalam kepemimpinan rumah tangganya, maka hal itu merupakan upaya yang sangat baik dalam menjaga keutuhan rumah tangganya. Orang Bugis biasanya melakukan sosialisasi dalam keluarga tentang petuah-petuah seperti ini dan akan tumbuh dari individu menjadi keluarga dan akhirnya akan menjadi satuan masyarakat yang menerapkan prilaku taro ada taro gau.

Dengan demikian, semakin tampak prilaku komunikasi orang Bugis yang telah mengalami proses akulturasi ajaran Islam. oleh karena itu, pengaruh Islam sangat dominan dalam membentuk prilaku orang Bugis, dimana ajaran Islam sangat mengutuk orang yang memiliki perbuatan yang menyimpang dari perkataannya. Bahwa amat besar kebencian Allah pada orang yang mengatakan 
sesuatu yang tidak sesuai dengan perbuatan yang dilakukannya. ${ }^{15}$

Konsep taro ada taro gau memiliki sebuah nilai kepemimpinan yang ideal bagi sebuah kepemimpinan dalam rumah tangga untuk mewujudkan keluarga yang sakinah. Nilai itu adalah macca, malemppu, magetteng dan manini.

Macca atau to acca dapat diartikan sebagai seorang yang ahli atau cerdik. Seorang pemimpin atau kepala keluarga harus memiliki sifat macca dalam mengurus rumah tangganya. Kecerdasan atau kepintaran merupakan hal penting dalam menguus rumah tangga misalnya dalam hal pengambilan keputusan, baik buruk nya situasi dan kondisi yang terjadi, maka kepintaran diperlukan dalam pengambilan keputusan yang terbaik.

Malempu atau jujur. Dalam bahasa bugis lempu berarti lurus, lawan dari kata bengkok. Dalam berbagai konteks andalannya lempu juga berarti ikhlas, sabar, baik atau adil. Nilai lempu juga merupakan kunci keberhasilan orang Bugis, dan sebaliknya akan menjadi penghancur bagi mereka yang tidak dapat berkata jujur. Nilai lempu tidak terlepas dari ajaran agama Islam dan menjadi panutan bagi masyarakat Bugis. perintah untuk senantiasa berkata jujur (lempu) terdapat dalam QS.At-Taubah/ 9:119:

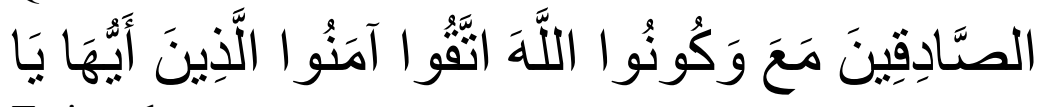

Terjemahnya:

Hai orang-orang yang beriman bertakwalah kepada Allah, dan hendaklah kamu bersama orang-orang yang benar. ${ }^{16}$

Kejujuran adalah salah satu syarat mutlak seorang pemimpin. Rasulullah SAW bersabda, "Tiada seorang yang diamanati oleh Allah memimpin rakyat kemudian ketika ia mati ia masih menipu atau membohongi rakyatnya, melainkan pasti Allah mengharamkan baginya surga" (HR al-Bukhari dan Muslim).

Magetteng (teguh/tidak ragu) merupakan nilai dasar orang Bugis yang berarti ketegasan atau keteguhan berpegang pada keyakinan yang benar. Nilainilai ini penting untuk diteladani bagi setiap pemimpin rumah tangga agar tidak mudah goyah dan kokoh dalam mengambil keputusan terbaik dalam rumah tangganya. ${ }^{17}$

Detik di mana kamu dinyatakan sah menjadi suami istri, saat itulah sudah tak ada lagi aku maupun kamu, tapi semua menjadi 'kita'. Menikah berarti mengesampingkan ego. Semua keputusan dan juga kepentingan sudah saatnya tak bersentris terhadap diri sendiri, tapi mengedepankan kepentingan keluarga.

15 Ahmad Sultra Rustam, Pola Komunikasi Orang Bugis. (Yogyakarta, Pustaka Pelajar Cet. 1 Tahun 2018), h 343-347.

${ }^{16}$ Kementrian Agama RI. Al-Qur'an dan Terjemahnya, h.551.

${ }^{17}$ Ahmad Sultra Rustam, Pola Komunikasi Orang Bugis, h. 225. 
Manini adalah sikap atau tindakan yang penuh kehati-hatian atau waspada terhadap efek tindakan atau ucapan yang akan tertuju, baik pada orang lain maupun diri sendiri. Atas dasar itu orang Bugis dalam bertindak terlebih dahulu harus memikirkan akibat yang akan ditimbulkan sebelum melakukan suatu tindakan. Dengan kata lain accamingko ri'alemu jolo' (bercerminlah kedalam dirimu terlebih dahulu). Prinsip seperti ini wajib direalisasikan dalam kepemimpinan rumah tangga agar mampu saling menghargai antara suami istri dan memperoleh ketentraman dalam rumah tangganya.

Sikap manini ini berlawanan dengan sikap ceroboh dan tergesa-gesa seringkali berbuat atau bertindak sesuatu tanpa berfikir terlebih dahulu.akibat dari tindakan seperti ini maka dapat membawa dampak buruk bagi orang lain maupun diri sendiri.

\section{Faktor Pendukung dan Penghambat Dalam Kepemimpinan Rumah Tangga}

Tujuan pernikahan dalam Islam adalah untuk membangun rumah tangga yang tenang, tentram, bahagia dan sejahtera, diliputi oleh cinta kasih dan kasih sayang sebagaimana yang terdapat dalam QS Ar -ruum: 21 :

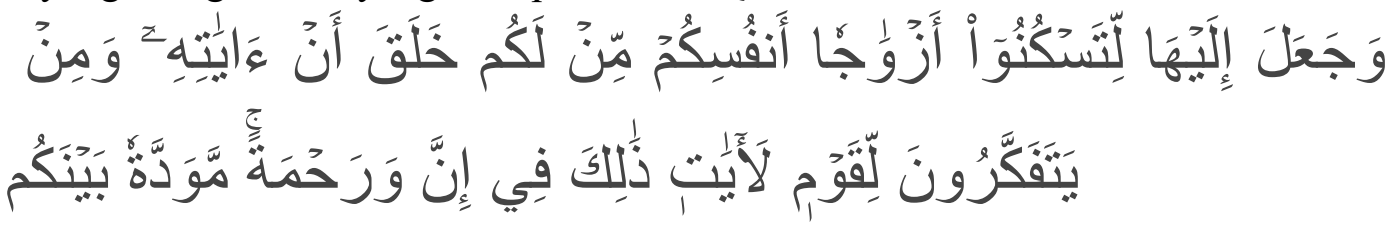

Terjemahnya :

Dan di antara tanda-tanda kekuasaan-Nya ialah Dia menciptakan untukmu isteri-isteri dari jenismu sendiri, supaya kamu cenderung dan merasa tenteram kepadanya, dan dijadikan-Nya diantaramu rasa kasih dan sayang. Sesungguhnya pada yang demikian itu benar-benar terdapat tanda-tanda bagi kaum yang berfikir. ${ }^{18}$

Keharmonisan akan tercipta dalam kehidupan keluarga bila diantara anggotanya saling menyadari bahwa masing-masing punya hak dan kewajiban. Keluarga yang harmonis adalah adanya komunikasi aktif diantara mereka terdiri dari suami-istri, anak dan siapapun yang tinggal bersama. Hubungan yang harmonis adalah hubungan yang dilakukan dengan selaras, serasi dan seimbang.

1. Faktor yang mendukung keberhasilan rumah tangga

\footnotetext{
${ }^{18}$ Kementrian Agama RI. Al-Qur'an dan Terjemahannya, h. 400.
} 
Menurut Abd. Rauf dalam buku saku pengantin, upaya yang perlu ditempuh untuk mewujudkan keluarga sakinah, ialah :

a. Komunikasi. Dengarkan pasangan . Hindari saling menyalahkan dan saling menghakimi. Jangan berasumsi, dan jangan biarkan emosi mendikte perilaku Anda.

b. Kepercayaan dan rasa hormat. Kepercayaan membuat pasangan suami istri merasa aman untuk bersikap terbuka, jujur dan apa adanya. Rasa hormat (respek) akan membantu pasangan untuk tidak saling menghakimi maupun mengkritik pendapat, perasaan dan keyakinan masing-masing.

c. Satu tim. Ketika masa-masa sulit mendera pernikahan, cobalah untuk selalu menyadari bahwa suami istri adalah satu tim. Pasangan suami istrilah yang akan merasakan kemenangan ataupun kekalahan dalam masalah tersebut. Saling mendukung dan bekerjasamalah. Hubungan dalam pernikahan tidak dimaksudkan untuk menjadi sebuah peperangan melawan satu dengan yang lain. Bahkan sebaliknya, Anda berdua harus berada pada sisi yang sama untuk melawan badai kehidupan.

d. Hadapi masalah yang muncul. Konflik adalah bagian alami dari sebuah hubungan. Menyadari perbedaan antara Anda berdua ketika menghadapi konflik akan menghindari perasaan buruk yang muncul dan dapat merusak hubungan yang baik. Jangan pernah menyimpan dendam; hadapilah setiap permasalahan itu lalu biarkan masalah itu pergi.

e. Berbagi tanggung jawab dalam pengambilan keputusan. Hubungan yang sehat terdiri dari kemitraan yang setara. Hal ini berlaku untuk keterlibatan dalam pekerjaan rumah tangga serta dinamika kekuasaan antara pasangan.

f. Bertengkar secara sehat. Menghakimi pasangan akan merusak hubungan Anda. Atasi perilaku Anda tanpa mengkritik orang lain. Mungkin Anda tahu titik-titik kelemahan dari pasangan Anda, tapi jangan pernah gunakan itu sebagai senjata selama konflik berlangsung. Jaga diri Anda sendiri. Ini adalah tanggung jawab Anda untuk mengetahui apa yang Anda inginkan dan tentukanlah bagaimana caranya untuk mencapai hal itu. Bila Anda membutuhkan pasangan Anda, buatlah permintaan yang jelas dan langsung. Sangat tidak dianjurkan bagi Anda untuk menyalahkan orang lain atas kegagalan yang Anda lakukan hanya untuk membenarkan diri sendiri. ${ }^{19}$

g. Perhatian, yaitu menaruh hati pada seluruh anggota keluarga sebagai dasar utama hubungan yang baik antar anggota keluarga. Baik pada perkembangan keluarga dengan memperhatikan peristiwa dalam

${ }^{19}$ Fathur Rahman, Psikologi Keluarga (Surabaya : Usaha Nasional, 1997), h. 121. 
keluarga,dan mencari sebab akibat permasalahan, juga terdapat perubahan pada setiap anggotanya.

h. Pengetahuan. Perlunya menambah pengetahuan tanpa henti-hentinya untuk memperluas wawasan sangat dibutuhkan dalam menjalani kehidupan keluarga. Sangat perlu untuk mengetahui anggota keluaranya, yaitu setiap perubahan dalam keluarga, dan perubahan dalam anggota keluarganya, agar kejadian yang kurang diinginkan kelak dapat diantisipasi.

i. Sikap menerima. Langkah lanjutan dari sikap pengertian adalah sikap menerima, yang berarti dengan segala kelemahan, kekurangan, dan kelebihannya, ia seharusnya tetap mendapatkan tempat dalam keluarga. Sikap ini akan menghasilkan suasana positif dan berkembangnya kehangatan yang melandasi tumbuh suburnya potensi dan minat darianggota keluarga. ${ }^{20}$

Oleh karena itu, dalam setiap rumah tangga, agar pernikahan mereka tetap bahagia dan harmonis, maka masing-masing pihak perlu berusaha untuk menjadi pendamping yang baik bagi pasangannya dengan mendahulukan tanggung jawab terhadap pasangannya dan bukan mendahulukan minat dan keinginannya sendiri. Demikian halnya dengan anggota keluarga yang lainnya, mereka perlu untuk selalu menjaga dan melestarikan hubungan keluarganya yang lebih harmonis lagi.

Kunci utama keharmonisan sebenarnya terletak pada kesepahaman hidup suami dan istri. Karena kecilnya kesepahaman dan usaha untuk saling memahami ini akan membuat keluarga menjadi rapuh. Makin banyak perbedaan antara kedua belah pihak maka makin besar tuntutan pengorbanan dari kedua belah pihak. Jika salah satunya tidak mau berkorban maka pihak satunya harus mau berkorban. Jika pengorbanan tersebut telah melampaui batasatau kerelaannya maka keluarga tersebut terancam. Maka fahamilah keadaanpasangan, baik kelebihan maupun kekurangannya yang kecil hinga yang tebesar untuk mengerti sebagai landasan dalam menjalani kehidupan berkeluarga. Rencana kehidupan yang dilakukan kedua belah pihak merupakan faktor yang sangat berpengaruh karena dengan perencanaan ini keluarga bisa mengantisiapsi hal yang akan datang dan terjadi saling membantu untuk misi keluarga.

2. Faktor Penghambat Keberhasilan Dalam Kepemimpinan Rumah Tangga

Rumah tangga yang harmonis bukan berarti tanpa konflik dan masalah. Justru berbagai masalah dan konflik akan menjadi pembuktian kedewasaan suatu hubungan. Karena sejatinya setiap masalah harus dihadapi dan dicari jalan

${ }^{20}$ Gunarsa, Singgih D \& Yulia Singgih D. Gunarsa. Psikologi UntukKeluarga. (Jakarta: Gunung Mulia1986), h. 42-44. 
keluarnya, bukan dihindari. Menurut Abd Rauf, hal yang dapat memicu konflik dalam rumah tangga seperti :

a. Komunikasi tidak lancar, hal ini merupakan salah satu masalah yang dialami oleh banyak pasangan, baik yang baru saja menikah maupun yang sudah lama menikah. Komunikasi yang tidak lancar dapat mengikis hubungan yang paling stabil sekalipun. Kesibukan masing-masing tak jarang menyebabkan komunikasi suami istri terhambat. Aktivitas yang berbeda mengakibatkan suami atau istri kekurangan waktu untuk berbincang, bercerita atau sekedar berbagai rasa, akibatnya akan timbul salah paham yang memicu pertengkaran.

b. Keintiman juga masalah umum yang dialami oleh banyak pasangan, dan seringkali menjadi manisfestasi dari berbagai masalah lainnya dalam perkawinan. Kurangnya seks dan keintiman bisa dijadikan hukuman bagi pasangan setelah bertengkar. Soal seks memang menjadi hal penting bagi pasangan suami istri. Jika salah satu pihak tidak terpenuhi kepuasan seksnya, bisa memicu pertengkaran bahkan perselingkuhan.

c. Ketidaksetiaan dan perselingkuhan, faktor paling kuat yang dapat menyebabkan keretakan rumah tangga adalah ketidaksetiaan dan perselingkuhan. Biasanya, hal ini terjadi sebagai hasil hubungan yang telah lama tidak sehat. Pasangan yang merasa percaya diri dengan hubungan mereka tidak akan mencari orang lain untuk bahagia.

d. Keuangan, Keuangan memang menjadi permasalahan yang pelik ketika dua orang bersatu dalam ikatan pernikahan. Biasanya masalah keuangan ini terjadi bila suami berpenghasilan kecil dan tidak mencukupi kebutuhan hidup dalam rumah tangga, sehingga istri menjadi seringkali emosi dan tidak patuh pada suami dari mulai biaya pernikahan hingga biaya hidup sehari-hari, uang bisa jadi masalah besar bagi sebuah rumah tangga. ${ }^{21}$

e. Pertengkaran dan konflik, perdebatan, perbedaan dan kesalahpahaman adalah bagian dari rumah tangga. Jika Anda sering bertengkar karena hal yang sama, atau berdebat dengan cara yang tidak sehat. Pernikahan sejatinya adalah menyatukan dua insan yang berbeda. Perbedaan itu mencakup banyak hal seperti latar belakang, sifat, karakter, kebiasaan dan juga kepribadian. Hal inilah yang menyebabkan sebuah rumah tangga menjadi lebih berwarna. Akan tetapi tak jarang juga perbedaan ini menyebabkan ketikakcocokan antara kedua insan manusia ini yang akhirnya menyebabkan masalah dalam rumah tangga, Memiliki pendapat yang berbeda itu wajar, hanya saja ketika ego sudah tidak dapat

${ }^{21}$ Rauf. Abd. Buku Saku Pengantin.(Majene.2011), h. 37. 
dikendalikan, menyebabkan kondisi atau suasana menjadi memanas dan tidak harmonis. $^{22}$

Problematik rumah tangga juga sudah seharusnya hanya dijadikan sebagai bumbu pemanis yang mampu merekatkan hubungan. Rasulullah SAW bersabda: Janganlah seorang suami membenci istrinya dengan kebencian yang besar karena di balik kebencian itu pasti ada sesuatu yang disukainya dari sosok istrinya itu.

Faktanya, hampir sebagian besar pasangan meributkan hal yang sama dalam pertengkarannya. Tentang uang, pekerjaan rumah tangga, keintiman, dan hal-hal lainnya yang menjadi sumber masalah. Menurut pakar hubungan Sheryl Paul, MD dikutip dari Huffington Post, banyak pasangan mendebatkan hal yang sama setiap hari karena mereka tidak tahu bagaimana komunikasi harusnya dibangun. $^{23}$

\section{SIMPULAN}

Berdasarkan masalah yang diteliti dalam kaitannya dengan temuan dan analisis penelitian yang telah dikemukakan, maka dapat dirumuskan dua kesimpulan pokok, sebagai berikut:

Proses penerapan nilai-nilai dakwah dalam lontara taro ada taro gau dalam kepemimpinan rumah tangga yaitu macca, dalam hal ini seorang pemimpin rumah tangga harus memiliki sifat pintar agar dapat menjadi teladan yang baik bagi keluarga yang dipimpinnya, dan mampu mengayomi serta menjadi panutan bagi keluarganya. Malempu, modal utama seorang pemimpin ialah harus mempunyai sifat yang jujur, kejujuran yang tinggi bertujuan agar kepemimpinannya tetap sejalan dengan syariat Islam, sebagaimana islam menganjurkan untuk selalu menanamkan sifat-sifat kejujuran bagi ummat muslim. Magetteng na warani, pemimpin harus mempunyai sifat kuat dan berani karena peran dan tanggung jawab seorang kepala keluarga sangat mempengaruhi keharmonisan dalam keluarga. Dan sifat Manini juga merupakan hal yang harus ada dalam jiwa seorang pemimpin rumah tangga, agar setiap tindakan yang diambil selalu dipertimbangkan dengan matang supaya tidak terdadi dampak yang buruk di kemudian hari bagi kelangsungan hidup rumah tangganya.

Faktor pendukung dan penghambat proses penerapan nilai-nilai dakwah dalam lontara taro ada taro gau di Kabupaten Bone yaitu:

Faktor yang pendukung dalam penerapan nilai-nialai dakwah dalam

\footnotetext{
${ }^{22} \mathrm{http}: / /$ www.astaga.com/hubungan-relationship/10-penyebab-dan-solusi-masalah-dalamrumah-tangga. Diakses pada tanggal 17 Juli 2019. Jam 22.31 WITA.

${ }^{23}$ Abd Rauf. Buku Saku Pengantin.(Majene.2011), h.33.
} 
lontara taro ada taro gau ialah, menjalin komunikasi yang baik antara suami istri, menumbuhkan rasa kepercayaan dan rasa saling menghormati, meberi perhatian baik suami kepada istri, istri kepada suami dan kepada anak-anaknya, dan memberikan pendidikan.

Faktor yang menjadi penghambat dalam menerapkan nilai-nilai dakwah dalam lontara taro ada taro gau ialah, komunikasi yang tidak efektif, kondisi ekonomi yang tidak berbanding lurus dengan gaya hidup, ketidaksetiaan dan perselingkuhan.

\section{DAFTAR PUSTAKA}

Amir Syarifuddin, Hukum Perkawinan Islam di Indonesia, Kencana, Jakarta, 2006.

Ayatrohaedi, kepribadian Budaya Bugis: Lokal Genius Jakarta: Pustaka Jaya, 2006.

Abd Rauf. Buku Saku Pengantin. Majene. 2011.

Ahmad Sultra Rustam, Pola Komunikasi Orang Bugis. Yogyakarta, Pustaka Pelajar Cet. 1 Tahun 2018

Fathur Rahman, Psikologi Keluarga. Surabaya : Usaha Nasional, 1997

Gunarsa, Singgih D \& Yulia Singgih D. Gunarsa. Psikologi UntukKeluarga. Jakarta: Gunung Mulia, 1986.

https://www.scribd.com/doc/315538155/Hakikat-Dan-Tujuan-Pernikahan-dalamIslam. Diakses pada 16 Juli 2019.

http://www.astaga.com/hubungan-relationship/10-penyebab-dan-solusi-masalahdalam-rumah-tangga. Diakses pada tanggal 17 Juli 2019. Jam 22.31 WITA.

Kementrian Agama RI. Al-Qur'an dan Terjemahannya, Jakarta, Direktorat Jendral Bimbingan Masyarakat Islam dan Urusan Agama Islam dan Bimbingan Syariah, 2012.

M. Husain Fadlullah, Metodologi Dakwah Dalam Al-Qur'an. Jakarta: Lentera. 1997.

M Arifin, Psikologi Dakwah suatu Pengantar. Jakarta. Bumi aksara. 1997.

M.John Echols dan Hassan Sadly, an Englis-Indonesia Dictionary: Kamus Inggris Indonesia Cet XXXIII: Jakarta: Gramedia Pustaka, 2006 
Rahmatunniar, "Kontekstualisasi Pangngadereng dalam Penegakan Syariat Islam pada Masyarakat Bugis Bone" (Al-Qalam 17, no. 1, 2011), h. 98-99. Diakses 14 September 2019

Siti Muriah,. Metodologi Dakwah Kontenporer. Yogyakarta: Mitra Pustaka. 2000.

Undang-Undang No.1 Tentang Perkawinan, Arkola, Surabaya. 1974

Yusuf Qardhawi, Al-Qur'an Berbica tentang Akal dan ilmu Pengetahuan. Jakarta: Gema Insani Press, 1998.

Zakiah Darajat, Dkk. Dasar-Dasar Agama Islam. Jakarta: Bulan Bintang, 1984. 